\title{
RAGAM BRANDING DESA DALAM MENGEMBANGKAN POTENSI WISATA BERBASIS BUDAYA MASYARAKAT DI KABUPATEN BULELENG
}

\author{
Ni Made Ary Widiastini \\ Universitas Pendidikan Ganesha \\ Email: ary.widiastini@gmail.com \\ Putu Indah Rahmawati \\ Universitas Pendidikan Ganesha \\ Email: Putuindah@yahoo.co.id \\ Fajar Yualida Isti Koma \\ Universitas Pendidikan Ganesha \\ Email: fajaryualida@gmail.com
}

\begin{abstract}
This paper aims to describe the image and branding of the cultural potential of a tourist destination in Buleleng Regency, so that each destination can be understood to have a different and unique identity. Buleleng Regency has natural and cultural potential that can be managed and utilized as tourist attractions. The potential can be packaged so that it becomes something that shows the identity of a destination. The large number of same turist destinations requires the accuracy in its management, so that the target market can be achieved. Brand and image become very important as a distinguishing destination between one another. In Buleleng Regency, several places have been developed by create the brand and image as tourist destinations, such as the Old Village of Buleleng Regency which consists of seven villages, Janger Kolok Bengkala Village, Bukakak Tradition, Sudaji Village, Beji Temple, Sangsit Village, Gedong Kerta and Puri in Paket Agung Village, dan Vihara in Banjar Village. In its implementation, it is recommended that brand and image formation must also be accompanied by the provision of facilities and services in accordance with the image being built.
\end{abstract}

Keywords: Brand, Image, Tourism, Buleleng 


\section{Pendahuluan}

Kabupaten Buleleng memiliki potensi alam dan budaya yang dapat dikelola dan dimanfaatkan sebagai daya tarik wisata. Secara normatif, Kabupaten Buleleng telah menetapkan delapan puluh enam daya tarik wisata melalui Peraturan Bupati Nomor 51 Tahun 2017 dan tiga puluh satu desa wisata melalui Keputusan Bupati Buleleng Nomor 430/405/HK/2017, tentang Desa Wisata. Kabupaten Buleleng secara keseluruhan memiliki luas wilayah 136.588 hektar atau 24.25\% dari luas Propinsi Bali. Sebagian besar wilayah Kabupaten Buleleng merupakan daerah berbukit yang membentang di bagian Selatan, sedangkan di bagian Utara yakni merupakan dataran rendah. Kabupaten Buleleng yang terdiri atas sembilan kecamatan, masing-masing kecamatan memiliki ragam sumber daya baik alam maupun budaya yang sesungguhnya dapat dikelola dengan baik untuk menghasilkan manfaat ekonomi bagi masyarakat dan daerah. Melakukan konversi sumber daya alam dan budaya yang tersedia menjadi sumber daya ekonomi melalui pariwisata sejalan dengan gagasan Chen dan Tsai (2006) yang menjelaskan bahwa pariwisata merupakan kekuatan pendorong pembangunan daerah. Pariwisata yang sukses dapat meningkatkan penerimaan turis, pendapatan, pekerjaan, dan pendapatan pemerintah, sehingga perlu kajian tentang pengembangan pariwisata untuk menghasilkan teknik yang tepat dalam menarik wisatawan berkunjung, mengunjungi kembali dan/atau merekomendasikan tujuan kepada orang lain untuk datang berwisata.

Memahami potensi-potensi tersebut, maka perlu dilakukan strategi yang tepat di dalam pengembangan Kabupaten Buleleng sebagai salah satu daerah tujuan wisata handalan yang memiliki karakterstik berbeda dengan jenis pariwisata yang dikembangkan di daerah lainnya, khususnya di Bali. Widiastini, Andiani, Trianasari (2012) menjelaskan bahwa dengan potensi yang beragam namun memiliki beberapa tantangan dan kelemahan, maka perlu adanya pengemasan wisata yang dapat 
menarik bagi wisatawan, baik lokal maupun internasional. Dalam hal ini, menyikapi era digitalisasi yang semakin berkembang, maka citra suatu produk dan/atau tempat wisata menjadi sangat penting dalam rangka mempublikasikan daya tarik wisata yang ada.

Digitalisasi sebagaimana yang dikemukakan Frank, Roehrig dan Pring (2014) menjelaskan bahwa terdapat tiga M yang harus dipahami dan dikuasai untuk menjadi digital yakni material bahan baku, mesin baru, dan model bisnis. Pada konteks ini, informasi daya tarik wisata harus dikaji dan dinarasikan dengan bagus sehingga menghasilkan informasi yang menarik, yang selanjutnya dipublikasikan dengan menggunakan sarana komunikasi yang sedang tren dan sesuai dengan alat komunikasi yang dikuasai oleh pasar atau target konsumen. Pada era digital produk yang dijual dapat diketahui oleh konsumen, menarik hingga terjadi keputusan untuk membeli, Echtner dan Ritche (1991) menekankan bahwa di dalam memahami perilaku perjalanan konsumen perlu dilakukan perancangan pemasaran pariwisata yang efektif dengan mengembangkan kerangka kerja dan metodologi konseptual yang lebih spesifik dan komplek untuk mengetahui citra destinasi yang andal. Dalam hal ini, Kabupaten Buleleng harus mampu membentuk citra yang unik pada masingmasing daya tarik wisatanya, dengan harapan wisatawan sebagai konsumen sasaran dari produk yang dikembangkan memiliki rasa ingin tahu informasi tentang produk yang ditawarkan melalui smartphone atau media elektronik lainnya hingga memutuskan untuk datang untuk berwisata.

Promosi suatu daerah tujuan wisata memerlukan kepekaan terhadap berbagai faktor eksternal, sebagaimana Govers, Go dan Kumar (2007) yang menegaskan bahwa banyak sumber informasi yang memiliki pengaruh terhadap pembentukan citra suatu destinasi, sehingga diharapkan otoritas pariwisata memahami pengaruh eksternal yang memiliki peran penting di dalam promosi pariwisata. Pada sisi lain, Kotler dan Kellner (2012) menjelaskan bahwa branding memiliki pengaruh terhadap ingatan konsumen dan menciptakan suatu citra, sehingga brand suatu destinasi akan mampu 
membentuk suatu citra tertentu dalam benak wisatawan. Selanjutnya, Chen dan Tsai (2007) dan Bigne, Sanchez dan Sanchez (2001) mengungkapkan bahwa citra destinasi tidak hanya memengaruhi seorang calon wisatawan untuk mengambil keputusan, melainkan juga memengaruhi perilaku wisawatan selanjutnya, apakah ia akan kembali atau bahkan menyarankan orang lain untuk datang ke destinasi yang telah dikunjunginya. Dengan demikian, perlu adanya upaya untuk membentuk suatu branding destinasi yang tidak saja membuat wisatawan memilihnya menjadi tujuan wisata, tetapi lebih dari itu, ia akan memberikan rekomendasi kepada teman atau orang lain dengan berbagai media karena citra yang baik atas kualitas layanan wisata yang tersedia di destinasi tersebut. Tulisan ini bertujuan untuk mendeskripsikan citra dan branding potensi budaya suatu destinasi wisata yang ada di Kabupaten Buleleng, sehingga setiap destinasi dapat dipahami memiliki identitas yang berbeda dan unik.

\section{Branding dan Citra Sebagai Pembentukan Identitas Suatu Destinasi Wisata}

Pemasaran sebagai proses dimana suatu perusahaan menciptakan nilai bagi pelanggan dan membangun hubungan pelanggan yang kuat untuk mendapatkan nilai dari pelanggan sebagai imbalan (Kurtz, 2012; Kotler dan Kellner, 2013; Kotler dan Amstrong, 2014). Dalam hal ini, pemasaran suatu destinasi harus memerhatikan brand yang dibentuk oleh destinasi, yang berimplikasi pada citra destinasi tersebut di pikiran wisatawan. Branding (Blain, Levy dan Ritchie, 2005) merupakan hal yang penting sebagai pembeda, dalam hal ini membedakan destinasi satu dengan yang lainnya, yang diantaranya image, recognition, differentiation, dan brand messages. Secara khusus Govers dan Frank (2010) menjelaskan tentang brand suatu tempat (place branding) merupakan suatu kegiatan pemasaran yang menjadikan nama dan hal-hal lain yang menyertainya merupakan identitas dari tempat, yang membedakan tempat tersebut dengan tempat lainnya. Praktiknya, wajib ada hal menarik yang dijanjikan kepada wisatawan yang akan berkunjung ke tempat tersebut, sehingga pada tahap selanjutnya mampu menciptaan sebuah citra yang memengaruhi keputusan wisatawan untuk mengunjungi destinasi tersebut. 
Strategi branding sebagaimana dalam Schultz dan Barnes (1999) mendefinisikan sebagai suatu manajemen terhadap sebuah merek dimana di dalamnya terdapat beberapa kegiatan yang bertujuan untuk membentuk brand yang diinginkan. Schultz dan Barnes (1999) juga menjelaskan brand communication sebagai cara komunikasi tentang suatu brand terhadap konsumen misalnya melalui iklan, promosi, dan suatu kegiatan (event). Branding merupakan teknik pemasaran paling baik untuk tujuan kontemporer, dimana wisatawan dalam perkembangannya semakin mencari pemenuhan gaya hidup dan pengalaman daripada mengenali diferensiasi dalam elemen yang lebih nyata dari produk tujuan seperti akomodasi dan atraksi (Morgan dan Pritchard, 2004). Memahami tuntutan wisatawan, implikasinya adalah bahwa setiap desinasi harus mampu untuk menciptakan identitas yang unik dengan tujuan untuk membedakan diri dari pesaing mereka, bahkan lebih baik dari yang sebelumnya mereka kunjungi. Praktiknya, untuk mampu bertahan hidup dalam pasar yang kompetitif secara global (Piggott dalam Morgan, dkk: 2004), maka setiap destinasi harus melihat potensi yang dimiliki dan menciptakan identitas yang unik serta menciptakan branding yang membuat wisatawan tertarik untuk berkunjung. Dalam penerapannya, branding mempengaruhi citra, oleh sebab itu dalam menciptakannya diperlukan kajian yang baik agar sebuah destinasi memiliki keunggulan yang membuatnya tetap mampu bertahan di tengah maraknya duplikasi model pengembangan destinasi dalam rangka meraih dan mempertahankan konsumen, yakni wisatawan.

Bigne, Sanchez dan Sanchez (2001) secara tegas menyatakan citra pariwisata adalah anteseden langsung dari persepsi kualitas, kepuasan, niat untuk kembali dan kemauan untuk merekomendasikan destinasi. Di dalam memperkenalkan suatu destinasi dibutuhkan gambar-gambar yang mampu mengomunikasikan hal-hal menarik yang ingin diungkapkan sehingga maksud dan makna dapat beriringan. Namun, perlu diperhatikan bahwa apapun yang ditampilkan harus disesuaikan dengan kualitas layanan serta produk yang ditawarkan. Hal ini perlu dipahami 
mengingat kualitas produk dan layanan akan berdampak kepuasan pengunjungan sekaligus memengaruhi keputusan mereka pasca berwisata ke destinasi tersebut. Echtner dan Ritchie (1991) juga menegaskan bahwa dalam pengembangan pariwisata, hal penting yang harus dipahami adalah bagaimana citra suatu destinasi yang dibentuk mampu memengaruhi sikap dan perilaku wisatawan. Pada konteks ini, sangat penting untuk membentuk suatu citra destinasi yang menarik untuk dikunjungi, menyenangkan saat wisatawan datang ke tempat tersebut, serta menjadi kenangan perjalanan yang indah bagi mereka sehingga promosi lanjutan pun dapat terjadi melalui wisatawan yang merasa puas pada saat berkunjung ke destinasi tersebut.

Citra destinasi (Tasci dan Gartner, 2007) menekankan sebagai aspek penting dalam keberhasilan pengembangan pariwisata dan pemasaran destinasi yang memiliki pengaruh terhadap sisi penawaran dan permintaan. Praktiknya wisatawan memiliki citra positif suatu destinasi dalam hal dimensi penerimaan, mereka lebih cenderung ingin mengunjungi kembali destinasi tersebut sebagai wujud dari kepuasan yang dirasakannya (Ross, 1993; Milman dan Pizam, 1995). Memahami citra sangat penting, maka pelaku pariwisata harus memahami dengan baik potensi suatu destinasi mulai dari pemberian nama suatu destinasi yang unik dan mudah diingat, serta mempertahankan citra yang dibentuk melalui pemberian layanan wisata yang berkualitas kepada wisatawan.

\section{Desa Wisata Di Kabupaten Buleleng}

Berlindung di bawah payung hukum yakni UU No.6 Tahun 2014 yang telah menetapkan bahwa desa sebagai ruang adminstrasi pembangunan, dimana dalam Pasal 83 ayat (2) UU No. 6 tahun 2014 dinyatakan bahwa pembangunan Kawasan Pedesaan dilaksanakan dalam upaya mempercepat dan meningkatkan kualitas pelayanan, pembangunan, dan pemberdayaan masyarakat desa di Kawasan Pedesaan melalui pendekatan pembangunan partisipatif, telah memberikan ruang 
gerak bagi Kabupaten Buleleng untuk mengembangkan desa wisata. Pada tahun 2017, melihat potensi yang dimiliki oleh tiga puluh satu desa, Keputusan Bupati Buleleng Nomor 430/405/HK/2017, tentang Desa Wisata pun ditetapkan. Namun, penetapan tersebut tentu membutuhkan kajian lanjutan dengan tujuan menciptakan sesuatu yang unik dan menarik pada masing-masing desa wisata tersebut. Pada penelitian ini, melalui pendekatan observasi dan literatur, diketahui bahwa terdapat hal unik terkait kebudayaan yang dimiliki oleh beberapa desa yang termasuk sebagai desa wisata dalam surat keputusan tersebut

\section{Desa Tua Kabupaten Buleleng}

Kabupaten Buleleng memiliki beberapa desa yang dikategorikan sebagai desa tua diantaranya Desa Sembiran, Desa Julah, Desa Sidatapa, Desa Cempaga, Desa Tigawasa, Desa Pedawa dan Desa Banyuseri. Desa- desa tersebut disebut dengan istilah Desa Bali Aga. Desa Bali Aga (Suacana, 2011) adalah desa pakraman yang masih tetap menganut tradisi pra-Majapahit, dimana secara etimologis dimaknai sebagai penduduk Hindu Bali yang mendiami desa-desa di wilayah pegunungan tanpa atau sangat sedikit dipengaruhi oleh budaya Hindu Jawa yang berasal dari Majapahit. Khusus, Desa Sembiran dan Desa Julah (Hauser-Schaublin, 2004) tidak mendiami pegunungan melainkan pesisir pantai timur laut Bali yang merupakan wilayah Timur Kabupaten Buleleng, dimana dijelaskan bahwa kedua desa tersebut adalah desa yang cenderung menolak pengaruh dari luar, sehingga terklasifikasi dalam komunitas yang tertutup. Desa Sembiran sebagaimana yang dijelaskan Murtana, dkk (2018), menjelaskan secara detail potensi yang dimiliki oleh desa tersebut, baik potensi budaya, alam, kesiapan sumber daya manusia, serta fasilitas yang mendukung. Begitupula Desa Julah (Schaublin, 2014) yang masih mempertahankan tradisinya tentu membutuhkan pendekatan khusus dalam pemanfaatannya sebagai desa wisata. Dalam hal ini, melihat masih dipertahankannya kehidupan tradisional oleh masyarakat setempat (Murtana, dkk: 2018) dengan mengadopsi gagasan Bandem (1998) menekankan pentingnya mengembangkan 
suatu desa menjadi desa wisata tanpa harus mengubahnya menjadi daerah yang bercorak desakralisasi dan profanisasi, serta menghindari produk massal dan tindakan komersialisasi.

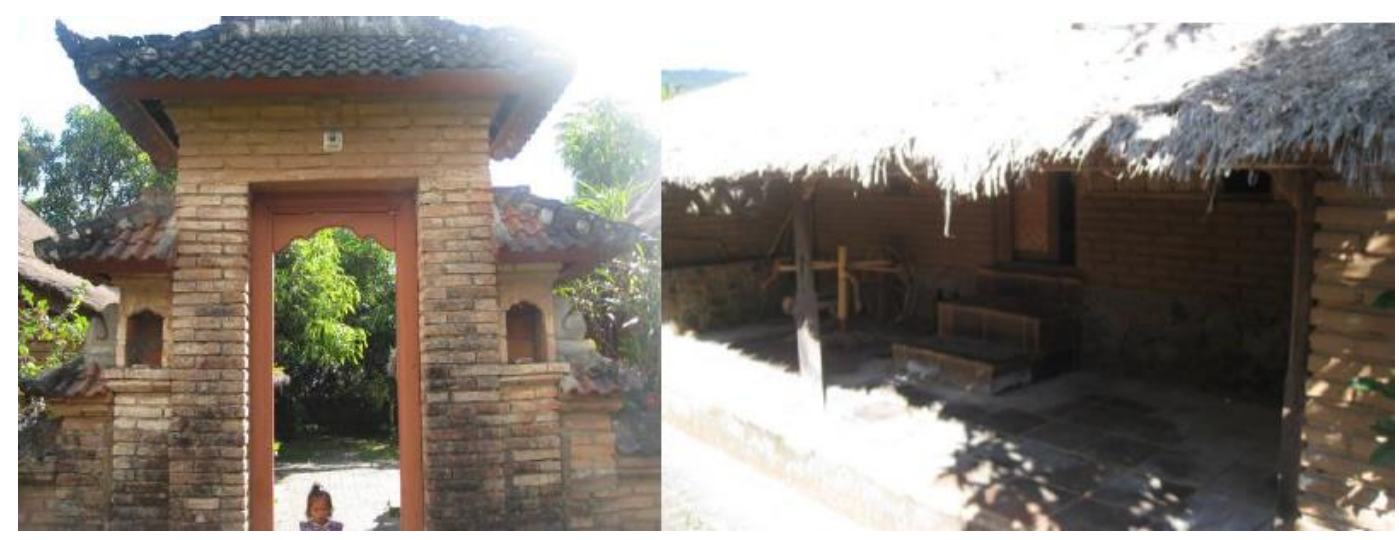

Gambar 1. Rumah di Desa Sembiran

Sumber: Widiastini, dkk (2011)

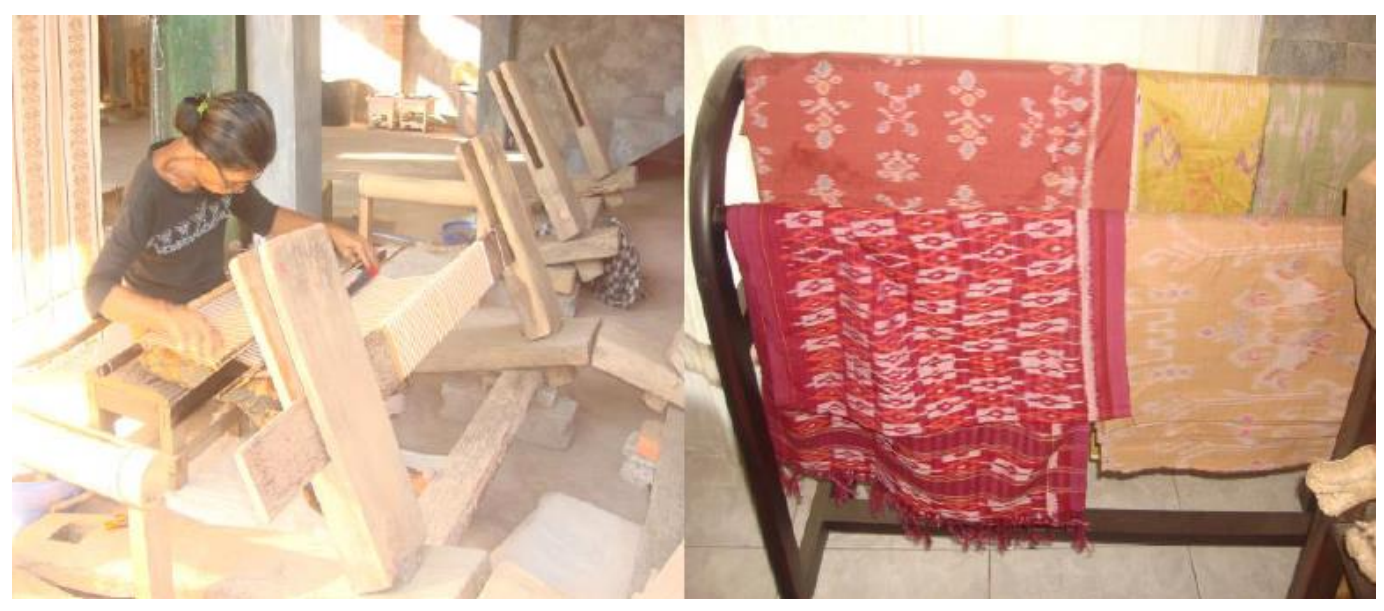

Gambar 2. Kerajinan Tenun Desa Julah

Sumber: Widiastini, dkk (2011)

Melangkah lebih maju, Desa Pedawa dan Desa Sidatapa bergerak cepat membentuk daerahnya sebagai Desa Bali Aga yang unik yang peduli dengan lingkungan. Kubu Hobbit (Bayuna, dkk: 2019), menjadi ikon Desa Pedawa yang menyuguhkan rumah dengan ukuran kecil. Sementara Desa Sidatapa (Yusuf dan Adnyana, 2019) menciptakan tradisi melepas burung sebagai bentuk peduli terhadap 
lingkungan. Pembentukan brand dan citra yang dilakukan oleh masyarakat yang ada di desa-desa yang termasuk sebagai desa tua di Kabupaten Buleleng, menjadi strategi yang baik untuk menggiring konsumen yakni wisatawan untuk mengunjungi destinasi di Kabupaten Buleleng sesuai dengan minatnya terhadap budaya.

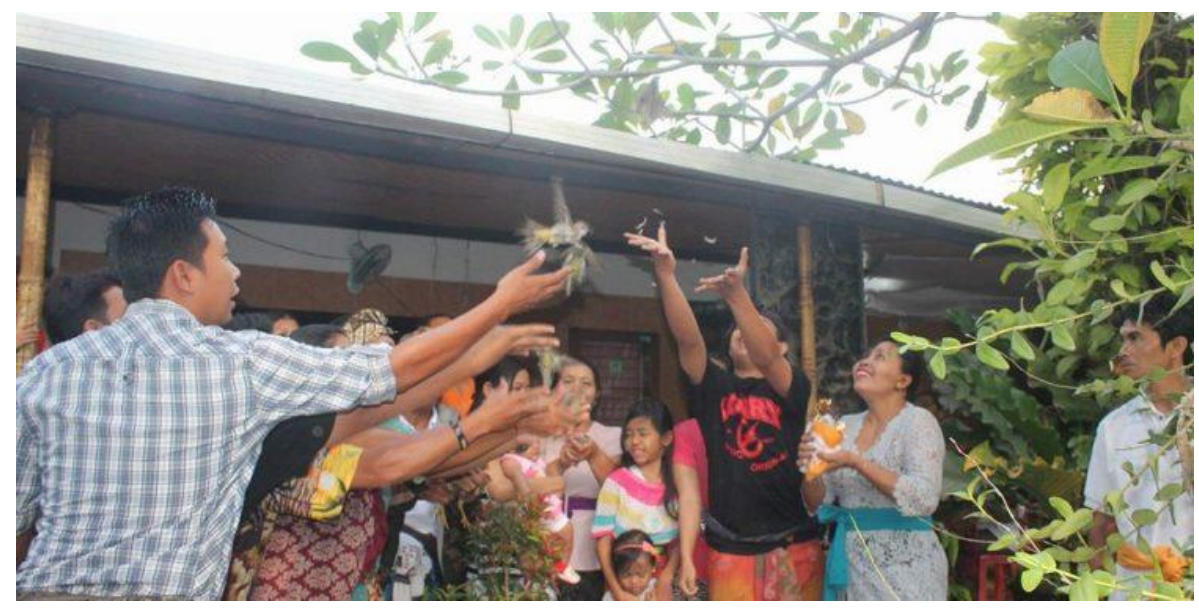

Gambar 3. Tradisi Melepas Burung ke Alam Bebas Sumber: Ariawan, 2017

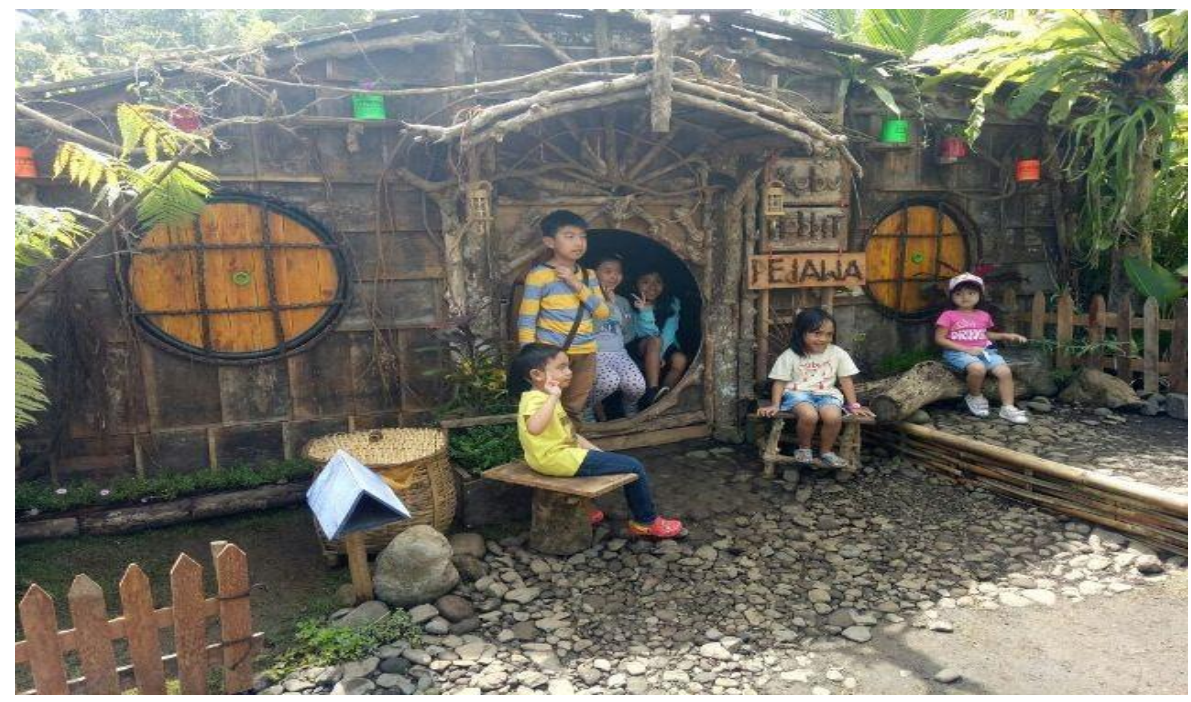

Gambar 4. Kubu Hobbit Desa Pedawa

Sumber: Mardika, 2017

Sebagai desa tua yang memiliki ke-khasan tradisi yang unik dan berbeda dengan desa lainnya, Desa Sembiran, Desa Julah, Desa Sidatapa, dan Desa Pedawa, begitu juga desa tua lainnya di Kabupaten Buleleng yakni Desa Tigawasa, Desa 
Cempaga dan Desa Banyuseri mampu membentuk brand sebagai destinasi wisata melalui citranya sebagai desa tua. Namun, tentu dalam perkembangannya, segala tradisi yang ada harus tetap mampu dipertahankan agar citra yang dibentuk dapat menjadi ikon destinasi yang berkelanjutan.

\section{Desa Kolok Bengkala}

Desa Bengkala yang merupakan salah satu desa wisata Kabupaten Buleleng memiliki keunikan yakni terdapatnya sekelompok masyarakata penyandang tuli bisu. Dalam keseharianya, masyarakat tersebut melakukan komunikasi dengan gerak tubuh yang sudah dipahami oleh satu sama lainya sesama penyandang tuna wicara. Prasetya (2018) menjelaskan bahwa masyarakat kolok di Desa Bengkala berada pada kondisi inklusi yang dipengaruhi oleh beberapa faktor yakni partisipasi masyarakat, hubungan interpersonal dan modal sosial yang dapat memberikan timbal balik bagi kehidupan masyarakat, terutama mereka yang cacat. Dijelaskan juga bahwa sebagian besar masyarakat Bengkala yang bukan kolok mengerti dan menggunakan bahasa orang kolok untuk berkomunikasi dengan kolok, kaarena bagi meerka bahasa orang kolok tersebut sederhana, sehingga mudah dipahami oleh penduduk Bengkala.

Desa Bengkala merupakan sebuah desa yang ada di Bali Utara, tepatnya di Kabupaten Kubutambahan, Kabupaten Buleleng. Sebagai desa yang memiliki populasi tuli sangat banyak (Marsaja, 2015), yang jumlahnya mencapai puluhan, menjadikan desa ini memiliki gelar sebagai Desa Kolok. Kolok secara harfiah yang memiliki arti tuli, maka Desa Kolok artinya desa yang dihuni oleh orang-orang yang tidak memiliki kemampuan mendengar (tuli). Jumlahnya yang banyak juga berimplikasi pada banyaknya orang datang berkunjung ke tempat ini untuk melihat aktivitas masyarakat di desa tersebut yang tidak bisa bicara. Bahkan, melihat banyaknya kunjungan orang dari luar ke desa ini, di desa ini pun dikembangkan suatu atraksi seni berupa tari-tarian. 
Memiliki keterbatasan komunikasi, kelompok disabilitas ini mampu dilatih untuk menari, sebagaimana yang dikembangkan oleh tokoh tari dari Institut Seni Indonesia berupa tari Baris Bebek Bingar Bengkala (Baris Bebila). Baris Bebila (Trisnawati dan Seramasara, 2019) adalah tarian yang menunjukkan suatu semangat kepahlawanan prajurit, yang merupakan paduan gerakan pertempuran, penggembala bebek serta ekspresi sebuah rasa gembiran yang tertuang dalam suatu tarian. Trisnawati dan Seramasara (2019) menjelaskan bahwa meskipun memiliki keterbatasan, orang-orang di Desa Bengkala, termasuk yang cacat yakni kolok, mempunyai bakat seni yang tinggi. Hal ini mempermudah para seniman luar untuk melatih tari bagi kelompok masyarakat kolok di Desa Bengkala.
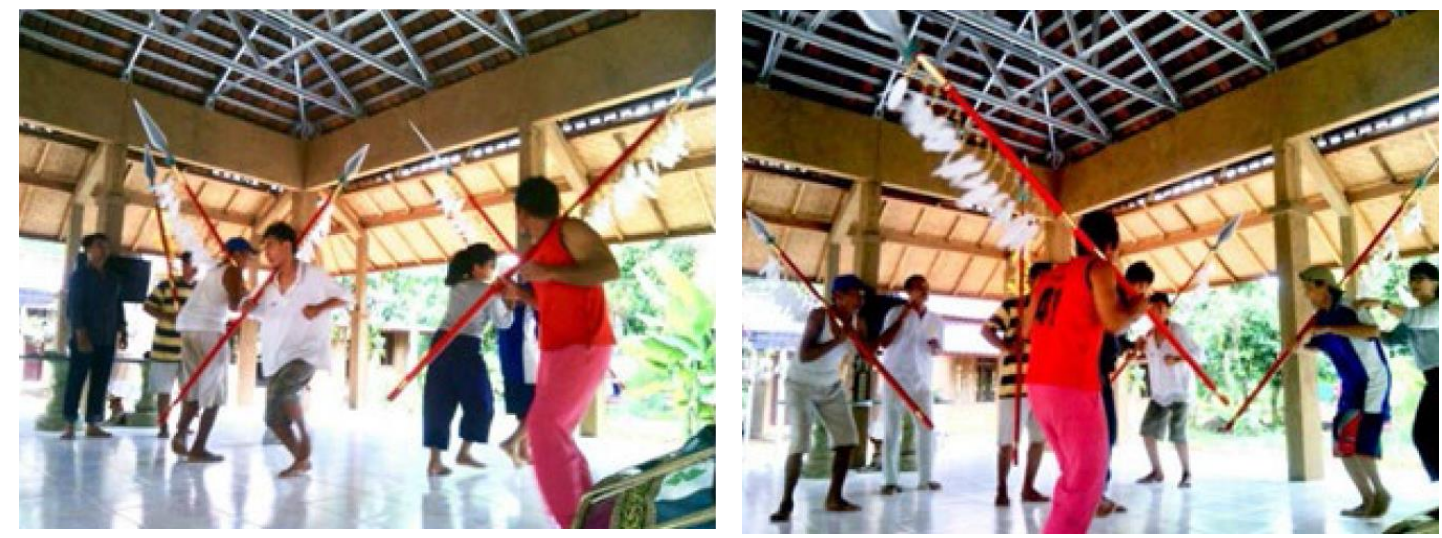

Gambar 5. Proses Penciptaan Tari Baris Bebila

Sumber: Trisnawati dan Seramasara (2019)

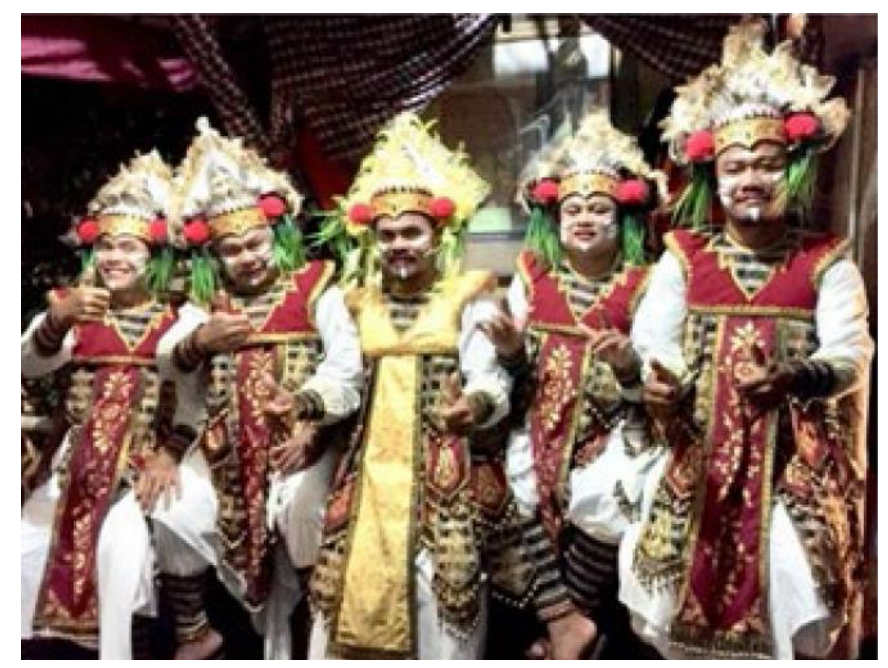

Gambar 6. Kostum Tari Baris Bebila

Sumber: Trisnawati dan Seramasara (2019) 
Masyarakat kolok yang terdapat di Desa Bengkala memiliki kelompok seni tari yang disebut dengan janger kolok, yang dalam perkembangannya telah menjadi idetitas desa tersebut. Janger kolok adalah tarian yang di mainkan oleh para penari yang tuna wicara (kolok) dengan jumlah penari sekitar 10-15 penari pria dan wanita yang berusia antara 20-60 tahun. Tarian yang seharusnya di nyanyikan dengan bersaut-sautan disini di pentaskan hanya dengan gerakan tubuh, mimic dan suara yang sangat terbatas yang di keluarkan oleh para penari. Selain itu kesenian janger kolok ini sangat unik dimana memperpadukan tiga unsur kesenian yakni janger, joged dan pencak silat. Masyarakat tuna wicara di Desa Bengkala membentuk sebuah sekaa Janger Kolok, dan dengan senang hati melakukan pementasan pada saat ada upacara keagamaan dan kegiatan-kegiatan yang berkaitan dengan pariwisata.

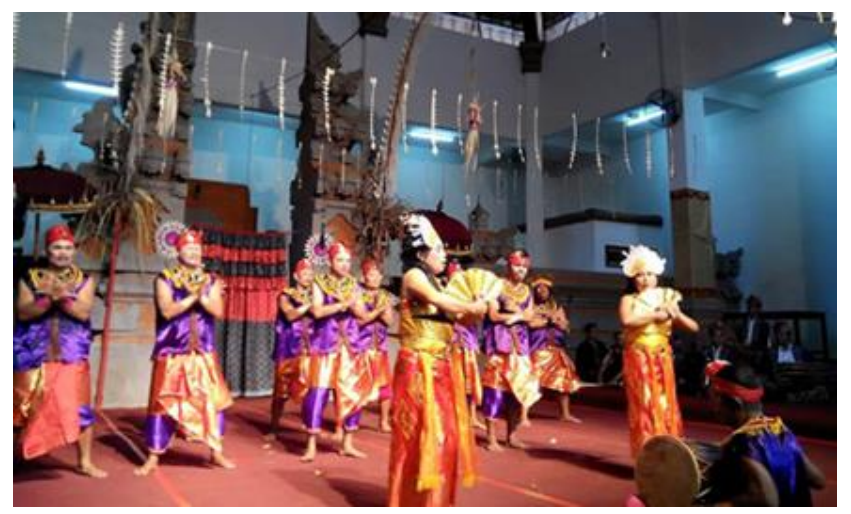

Gambar 7. Pementasan Janger Kolok Bengkala

Sumber: https://www.balitoursclub.net/desa-tunarungu-bengkala/, di akses tanggal 16 Maret 2020

Kelompok masyarakat kolok yang ada di Desa Bengkala memiliki semangat yang tinggi untuk bisa menunjukkan kepada dunia tentang kemampuan mereka. Trisnawati (58 tahun) yang merupakan salah satu tokoh seni tari di Bali yang juga dosen mengajar menari menjelaskan bahwa butuh waktu dua tahun untuk mengajarkan kaum disabilitas di Desa Bengkala (kelompok masyarakat kolok) untuk bisa menari tiga tarian. 
“Lumayan susah, tetapi semangat mereka luar biasa. Tyang sudah ajarkan mereka tiga tarian, dan mereka sudah bisa pentas menari baik di desa maupun di undang di hotel. Mereka pernah tampil di The One Legian, acara BRI se-Indonesia dan juga di Restaurant Kepiting Nusa Dua (Wawancara, 26 Maret 2020)".

Dalam wawancara yang dilakukan melalui media sosial (whatsapp), Trisnawati (58 tahun) menjelaskan bahwa mereka sesungguhnya kaum disabilitas yang memiliki semangat hidup yang tinggi. Melalui eksistensi mereka, Desa Bengkala memiliki brand sebagai desa kolok dengan seni tari mereka yang unik sebagai bagian dari budaya dalam kehidupan mereka.

\section{Tradisi Bukakak Desa Sudaji}

Desa Sudaji, Kecamatan Sawan memiliki beragam potensi wisata yang dapat dikembangkan khususnya dengan mengandalkan sumber daya alam pertaniannya (Putra dan Abdulah, 2018; Widiastini.dkk, 2018). Daya tarik wsiata yang telah dikembangkan oleh Desa Sudaji diantaranya trecking, wisata spiritual, agrowisata, pentas seni budaya, dan yang terbaru adalah berupa arung jeram. Selain itu, dimilikinya tradisi Bukakak yang jatuhnya bertepatan dengan waktu kunjungan wisatawan terbanyak yakni high season (pada bulan Juni hingga bulan Juli), menjadikan desa ini sangat potensial untuk mengembangkan desanya sebagai pariwisata pedesaan yang juga memanfaatkan potensi budaya sebagai salah satu atraksi wisatanya.

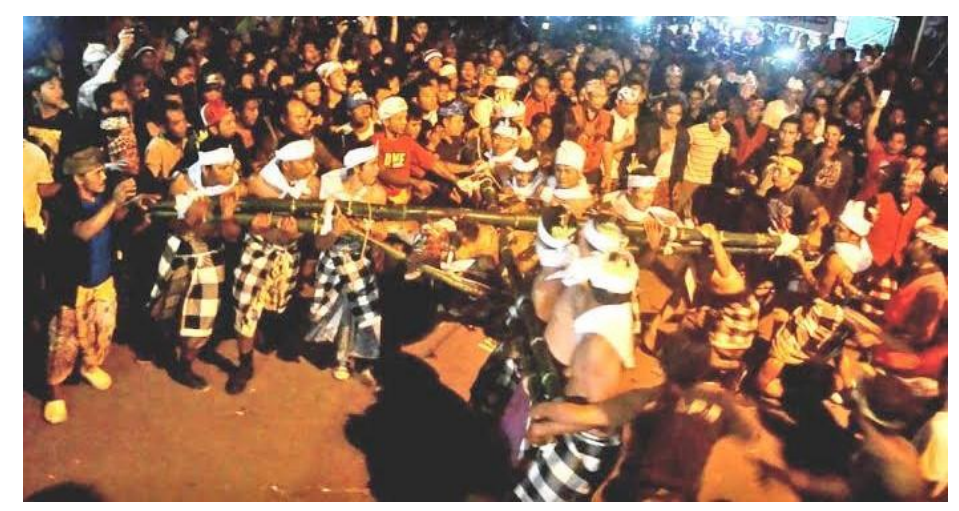

Gambar 8. Mengarak Bukakak Desa Sudaji, Buleleng Sumber: Gede Adi Wira Yastrawan, 2018 
Desa Sudaji memiliki tradisi unik yang disebut dengan Ngusaba Bukakak. Ngusaba Bukakak yang jatuhnya setiap Purnama Sasih Karo merupakan symbol wujud syukur para petani kepada Tuhan Yang Maha Esa atas kesuburan tanah yang diberikan sehingga mampu menghasilkan panen yang baik. Desa Sudaji merupakan masyarakat agraris dimana mayoritas masyarakatnya adalah petani, menjadikan upacara tersebut sebagai ritual wajib. Bahkan mereka percaya jika ritual tersebut tidak dilakukan, maka akan terjadi musibah terhadap masyarakatnya.
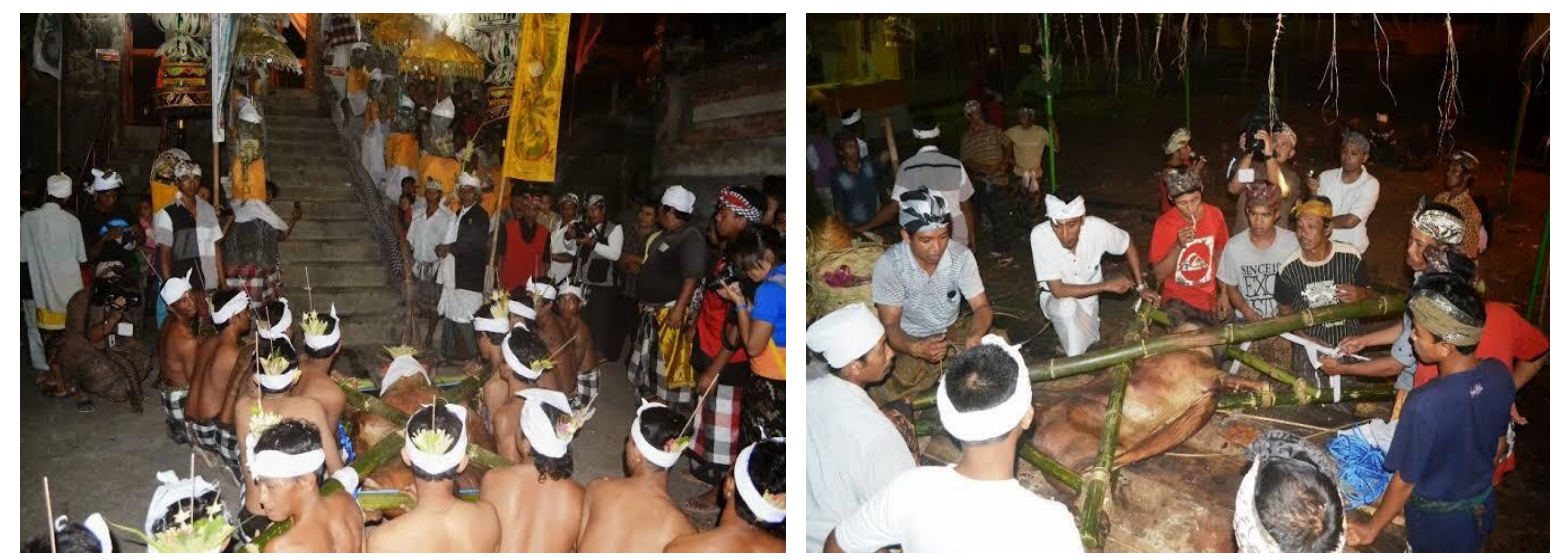

Gambar 9. Kegiatan Ritual Bukakak Desa Sudaji, Buleleng Sumber: Gede Adi Wira Yastrawan, 2018

Bukakak atau yang lebih dikenal dengan sebutan "Pekakak" adalah ritual tahunan yang dilaksanakan setelah Piodalan di Pura Desa. Ritual ini disungsung oleh Krama Subak sedesa Sudaji sebagai bentuk rasa syukur kepada Dewa Wisnu sebagai pemelihara (Wira, 2018). Ritual yang digelar setiap tahun dengan kegiatan ritual yang dilaksanakan selama sebulan, telah menjadi daya tarik khusus wisatawan untuk berkunjung ke Desa Sudaji, dan menginap pada homestay-homestay yang disediakan oleh masyarakat setempat.

Tradisi Ngusaba Bukakak merupakan upacara ritual adat yang bersifat religius, magis, dan unik, dan dilaksanakan secara turun-temurun oleh masyarakat setempat. Tujuan serta makna dari upacara Ngusaba bukakak adalah untuk memohon agar diberikan kesuburan kepada tanah-tanah pertanian pada masyarakat Desa dengan harapan supaya hasil panennya berlimpah ruah serta sebagai ucapan 
trimakasih kepada Tuhan yang Maha Kuasa (Justiasa, 2015). Tradisi Ngusaba Bukakak juga dilakukan di desa lain yang ada di sekitar Desa Sudaji, seperti Desa Sangsit, dimana tujuan dari ritual tersebut adalah sama yakni sebagai wujud terima kasih atas panen yang baik.

\section{Pura Beji Desa Sangsit}

Pura Beji Desa Sangsit (Prawira, 2013) menjelaskan diperkirakan ada pada abad ke lima belas, dimana pura tersebut dibangun atas faktor politik dan budaya. Selain itu, pura tersebut memiliki fungsi religius, fungsi sosial, fungsi pelestarian budaya dan fungsi pendidikan. Widiastini, dkk (2018), Desa Sangsit ditetapkan menjadi desa wisata tidak lepas dari adanya Pura Beji yang menjadi ikon dari desa tersebut. Selain berfungsi sebagai tempat persembahyangan umat Hindu oleh masyarakat setempat, adanya relief yang unik mampu menjadi daya tarik bagi wisatawan, khususnya wisatawan mancanegara. Bahkan, keunikan yang dimiliki, menjadikan pura ini sering digunakan sebagai tempat gambar untum pre-wedding, baik oleh masyarakat lokal maupun luar daerah.

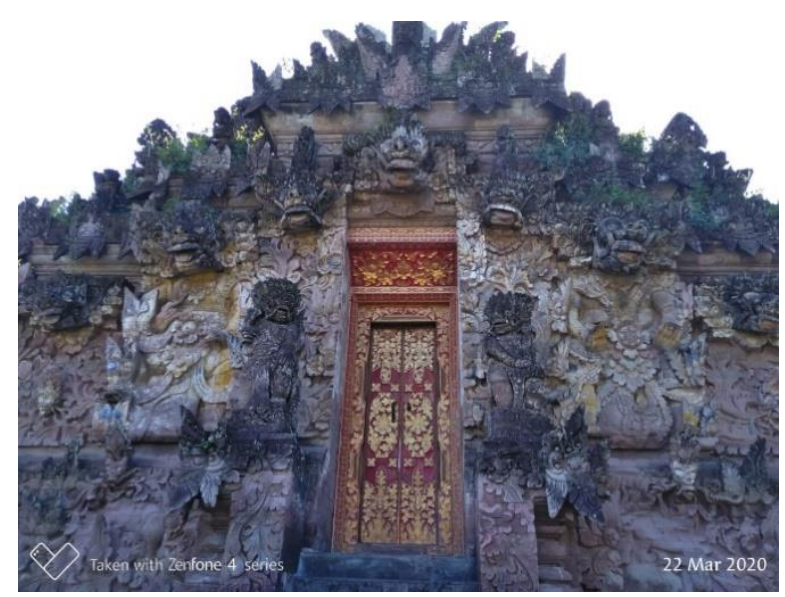

Gambar 10. Pintu Pura Beji, Sangsit, Buleleng Sumber: Komang Krisna Darmawan, 2020 


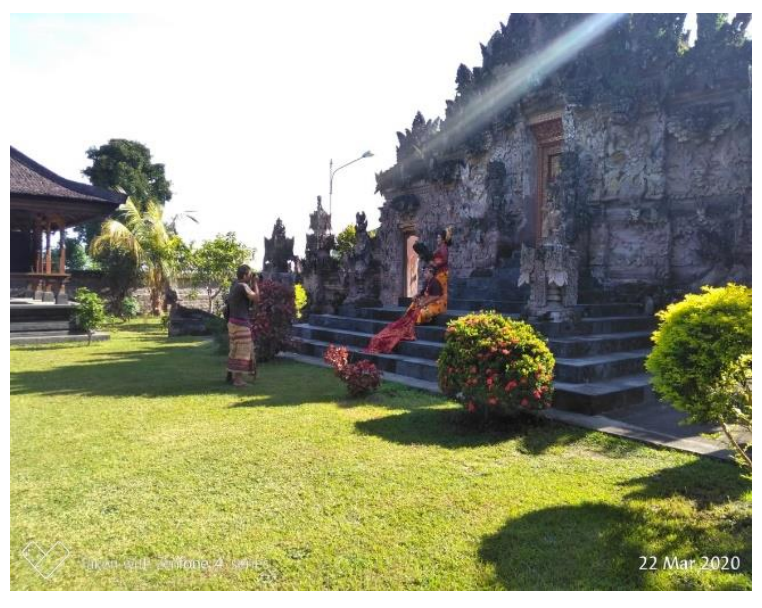

Gambar 11. Areal Pura Beji Sebagai Tempat Gambar Pre Wedding Sumber: Komang Krisna Darmawan, 2020

Pura Beji di Desa Sangsit (Prawira, 2013), menjelaskan bahwa pura tersebut telah menjadi cagar budaya dalam Undang-Undang No. 5/1992 tentang Cagar Budaya. Penetapan Pura Beji sebagai cagar budaya juga berimplikasi pemberian branding destinasi tersebut. Dalam hal ini, branding juga dapat dimiliki melalui peran eksternal, yakni pihak yang memiliki kewenangan dalam menetapkan undangundang. Struktur pura Beji Sangsit (Hasnawati, 2012) terdiri atas halaman pura, bangunan halaman terluar satu (jaba), bangunan halaman kedua (jaba tengah) dan bangunan pada halaman terdalam (jeroan). Pura ini menjadi daya tarik wisata karena keunikan ragam hias dna reliefnya yang dipengaruhi oleh budaya luar yakni Cina dan Eropa, sehingga menghadirkan ukiran yang unik. 

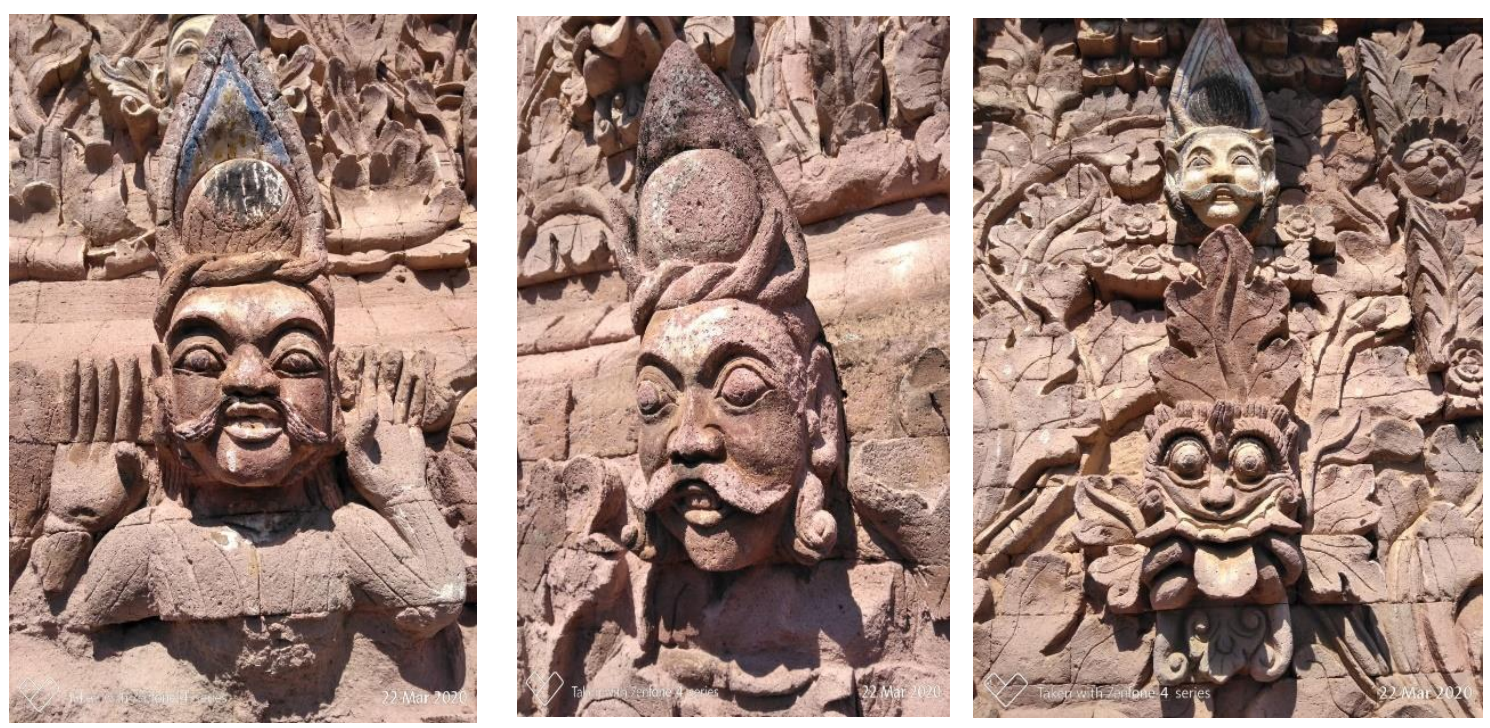

Gambar 12. Relief Pura Beji, Desa Sangsit, Buleleng Sumber: Komang Krisna Darmawan, 2020

Keunikan yang dimiliki oleh Pura Beji Sangsit yang menjadi daya tarik wisata berupa hiasan (Pramana, et.al.: 2015) meliputi (1) Pepatraan yakni patra punggel, patra ulanda, patra cina, patra sari; patra samblung; (2) Kekarangan yakni karang tapel, karang boma, karang sae, karang goak, karang simbar, dan karang asti. Pepatraan dan kekarangan merupakan ornamen yakni suatu dekorasi yang digunakan untuk membuat suatu media yakni bangunan menjadi indah dan menarik. Ornamen (Siwalatri, et.al, : 2012) dalam arsitektur tradisional Bali memiliki makna simbolis, historis, estetis dan alegoris. Ornamen adalah salah satu elemen arsitektural yang berfungsi sebagai media untuk mengekspresikan makna, khususnya dalam arsitektur tradisional.

Desa Sangsit yang terletak di Kecamatan Sawan, bukan satu-satunya desa yang memiliki keunikan pada hiasan puranya. Ada juga relief yang unik dapat ditemukan di Pura Meduwe karang dan Pura Dalem Jagaraga yang letaknya ada dalam satu kecamatan. Bentuk reliefnya yang unik diceritakan oleh Covarubias (1947) dalam bukunya "Pulau Bali". Pada pura Jagaraga tersebut terdapat bandit yang membawa pistol dan mengarahkan pistol ke dua pengendara mobil, mekanik yang memperbaiki 
mobil, dua orang gemuk yang minum bir, orang yang mengendarai sepeda, dan pesawat terbang (Putra dan Aditia, 2016). Relief -relief yang ada di ketiga pura tersebut dimaknai sebagai adanya bentuk akulturasi budaya, dimana tantangan bidang seni pada zaman itu mendapatkan respon oleh seniman Buleleng, sehingga menghasilkan hiasan yang unik dan menarik bagi wisatawan.

\section{Gedong Kertya dan Puri Buleleng di Desa Paket Agung}

Salah satu tempat yang memiliki nilai sejarah yang berada masih pada wilayah perkotaan adalah Desa Paket Agung. Namun, nama desa tersebut sering tidak diketahu karena terdapat dua tempat yang lebih dikenal yakni Gedong Kertya dan Puri Agung Singaraja. Gedong Kertya merupakan tempat penyimpanan lontar (Kesiman, dkk: 2016) dan Puri Agung Singaraja (Andiani, dkk: 2014) sebagai tempat raja Buleleng yang juga merupakan sastrawan angkatan Pujangga Baru. Kedua tempat ini tidak saja dikunjungi oleh wisatawan domestik, tetapi juga wisatawan mancanegara, khususnya mereka yang memikiki tujuan untuk meneliti dan/ atau memiliki ketertarikan pada bidang kebudayaan.

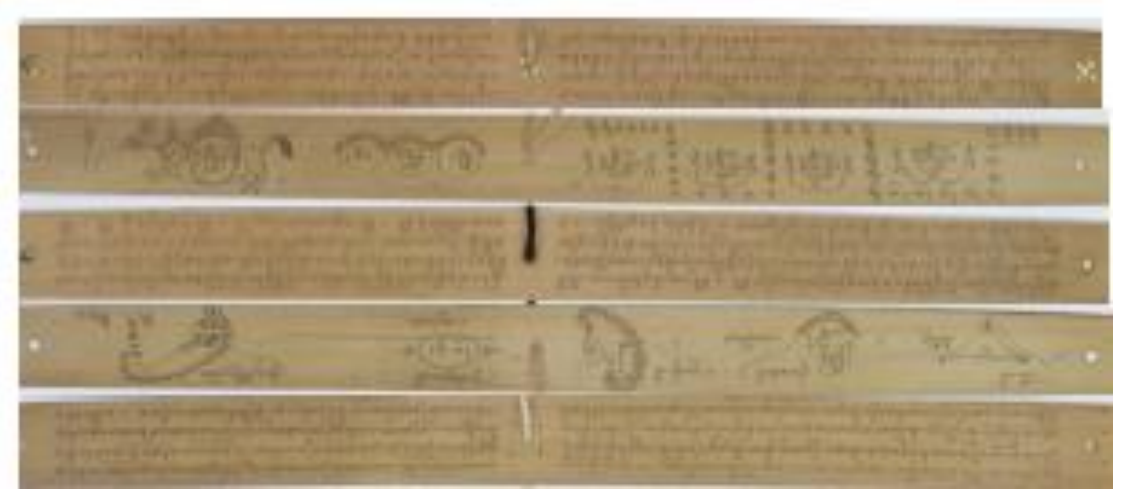

Gambar 13. Lontar Koleksi Museum Gedong Kertya Sumber: Kesiman, dkk (2016)

Gedong Kertya sebagai tempat yang menyimpan dan mengoleksi 1757 cakup lontar (Trinawindu., et.al: 2015) menjadi tempat yang dikunjungi oleh masyarakat umum maupun wisatawan yang ingin mempelajari tentang pengetahuan yang 
tertulis dalam lontar. Lontar (Trinawindu.,et.al: 2015) dijelaskan berfungsi sebagai buku yang memberikan informasi tentang cerita, puisi, pedoman kehidupan masyarakat Bali kuno, serta filsafat kehidupan masyarakat Hindu Bali. Penelusuran yang dilakukan Sudewa (2003) menjelaskan bahwa di museum lontar Gedong Kertya, jumlah lontar yang isinya tentang resep obat dan metode penyembuhan (usadha) sangat banyak. Menjadi museum yang menyimpan banyak informasi tentang kesehatan, membuat tempat tersebut banyak dikunjungi oleh masyarakat umum maupun wisatawan yang memiliki tujuan belajar tentang kesehatan.

Museum Geding Kertya didirikan pada tahun 1928, yang diperuntukkan bagi masyarakat umum, dengan beralamatkan di Jalan Veteran no. 20, Kelurahan Paket Agung, Kecataman Buleleng, Kabupaten Buleleng, Provinsi Bali. Pada museum ini terdapat manuskrip daun lontar, manuskrip kertas dalam Bahasa Bali dan huruf Romawi, juga terdapat dokumen yang merupakan peninggalan zaman kolonial. Koleksi lontar yang terdapat di dalam museum tersebut adalah Weda, Agama, Wariga (astronomi dan astrologi), Itihasa (Wiracarita), Babad (sejarah) dan Tantri. Sebagai peninggalan kerajaan, letak Gedong Kertya pun berdekatan dengan letak puri yang merupakan tempat tinggal raja. Letak museum Gedong Kertya berdekatan dengan Puri Agung Singaraja yang merupakan tempat tinggal Raja Buleleng, yakni sebelah Selatan museum tersebut.

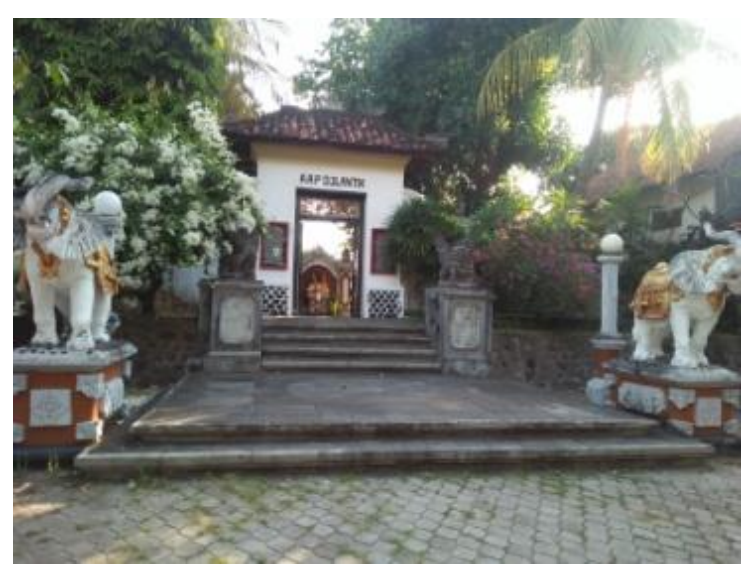

Gambar 14. Halaman Depan Puri Agung Singaraja Tempat Tinggal Raja Buleleng Sumber: Widiastini, dkk (2018) 
Peninggalan sejarah yang dimiliki oleh Kabupaten Buleleng, khususnya Puri Agung Singaraja tidak saja menyimpan cerita tentang kerajaan di Buleleng, tetapi lebih dari itu, terdapat cerita tentang kemampuan sastra yang dimiliki oleh raja terakhir yakni Anak Agung Pandji Tisna yang merupakan sastrawan Pujangga Baru. Novelnya Sukreni Gadis Bali, I Swasta Setahun di Bedahulu (Andiani, dkk: 2014), merupakan novel yang dikenal hingga ke luar negeri. Hingga saat ini banyak sastrawan baik lokal, nasional maupun internasional yang tertarik untuk mengunjungi puri tersebut untuk mendapat informasi tentang karya satra yang telah dihasilkan.

\section{Wihara Desa Banjar}

Desa wisata Banjar berada pada wilayah Kecamatan Banjar, Kabupaten Buleleng yang dikenal memiliki dua potensi yakni sumber daya alam berupa air panas dan sumber daya budaya yakni Wihara sebagai tempat ibadah agama Budha (Widiastini, dkk: 2018). Wihara tersebut bernama Brahmavihara-Arama merupakan wihara terbesar di Bali yang terletak pada tempat dataran tinggi dengan udaha yang sejuk dan suasana yang kondusif. Wihara ini tidak saja menjadi destinasi yang menarik bagi mereka yang memeluk agama Budha, tetapi juga bagi umum, baik wisatawan domestik maupun mancanegara.

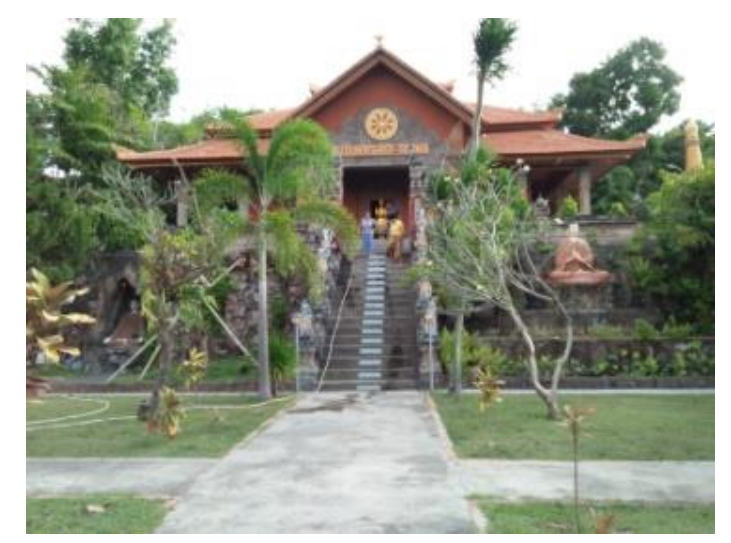

Gambar 15. Areal Brahmavihara-Arama, Desa Banjar, Buleleng Sumber: Widiastini, 2019 
Wihara tersebut juga sering digunakan sebagai tempat untuk meditasi oleh grup-grup yoga. Suasana yang tenang menjadikan Brahmavihara-Arama menjadi pilihan bagi mereka yang memiliki kegiatan rutin meditasi. Brahma Vihara Arama (Cahyawan dan Saliya, 2017) menjelaskan bahwa vihara tersebut adalah vihara pertama yang di bangun di Bali. Pembangunannya dilakukan setelah masuknya kembali Agama Buddha ke Indonesia sejak awal kemerdekaan Indonesia, yang selanjutnya menjadi pelopor dibangunnya vihara-vihara lainnya di Bali. Brahma Vihara Arama berada di di Banjar Tegehe, Desa Banjar yang termasuk sebagai salah satu data tarik wisata di Kawasan Pariwisata Kalibukbuk.

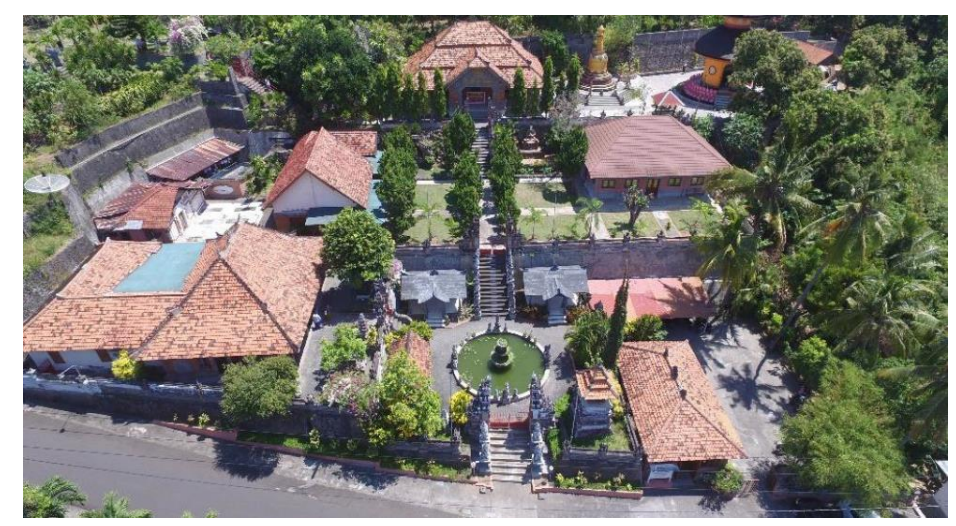

Gambar 16. Brahmavihara-Arama, Desa Banjar, Buleleng Sumber: Cahyawan dan Saliya, 2017

Wihara Brahma Budha (Abdillah, 2017) merupakan vihara agama Budha yang juga dikenal dengan nama Brahmavihara-Arama adalah sebuah vihara yang indah dan merupakan tempat ibadah umat Buddha terbesar di Bali. Letaknya yang ada di Banjar, menjadikan orang banyak menyebutnya Vihara Banjar. Wisatawan yang berkunjung ke Viraha Banjar ini tidak hanya mereka yang menganut agama Budha, tetapi juga agama lain. Tempatnya yang berada pada ketinggian 500 mdpl menyebabkan lokasi ini sejuk, di dukung dengan suasana yang tenang dan nyaman untuk bagi mereka yang suka melakukan aktivitas meditasi. 
Meminjam gagasan Ragheb LMS yang melakukan klasifikasi motivasi dengan mengadopsi model Maslow, salah satu dari empat kategori motivasi (Mahika, 2011) adalah competence of avoiding stimulus, yakni menunjukkan keinginan untuk melarikan diri dari situasi kehidupan yang penuh tekanan. Dalam hal ini, wisatawan tersebut memiliki tujuan untuk menghindari kontak sosial, mencari kedamaian dan relaksasi. Memiliki ruang yang nyaman untuk melakukan meditasi, suasana yang tenang, dan cuaca yang sejuk, menjadikan Desa Banjar ini dikenal sebagai desa yang memiliki wihara yang dapat dikunjungi oleh orang dengan tujuan competence of avoiding stimulus.

\section{Penutup}

Pariwisata merupakan industri yang sangat bergantung dengan branding dan citra, sehingga sangat penting bagi pihak yang terlibat dalam pemasaran pariwisata memahami strategi yang tepat untuk menciptakan brand dan citra atas suatu destinasi. Hal tersebut juga bertujuan untuk menjadi pembeda suatu destinasi antara satu dengan lainnya. Selain itu, memahami brand sebagai dasar penentu wisatawan memilih suatu destinasi, maka suatu daerah harus diberikan brand sesuai dengan sumber daya atau potensi yang dimilikinya. Praktiknya, pembentukan citra yang baik juga harus disertai dengan penyediaan fasilitas dan layanan yang sesuai dengan citra yang di bangun, sehingga kepuasan wisatawan dapat terwujud.

\section{Daftar Pustaka}

Andiani, Nyoman Dini. Ni Made Ary Widiastini. Nyoman Trisna Herawati. 2014. Pengembangan Puri Agung Singaraja Sebagai Daya Tarik Wisata Sastra. Seminar Nasional Riset Inovatif II, Tahun 2014. ISSN: 2339-1553.

Bandem, I Made. 1998. Peranan Seni dan Budaya Sebagai Komoditas Dalam Pengembangan Industri Pariwisata. Seminar Nasional Pariwisata Budaya Program Magister (S2) Kajian Budaya Universitas Udayana Denpasar. Tidak Terbit. 
Bayuna, Gede Riko. Anantawikrama Tungga Atmadja. Nyoman Trisna Herawati. 2019. Penentuan Harga Pokok Produksi Pada Gula Aren Asli Pedawa di Desa Pakraman Pedawa. Jurnal Ilmiah Mahasiswa Akuntansi Undiksha. Volume 10. Nomor 1.

Blain, Carmen. Stuarte Levy dan J.R. Brent Ritchie. 2005. Destination Branding: Insights and Practices from Destination Management Organizations. Journal of Travel Research. Volume 43, May 2005, 328-333

Bigne, Enrique J. M. Isabel Sanchez dan Javier Sanchez. 2001. Tourism Image, Evaluation Variables and After Purchase Behaviors: Inter-relationship. Tourism Management. Volume 22, Issue 6, December 2001, Pages 607 - 616

Cahyawan, Meidy Charista. Yuswadi Saliya. 2017. Similarities and Differences in The Spatial Pattern and Form of Buddhis Buildings of Worship on Bali. Jurnal RISA (Riset Arsitektur). Volume 01. Nomor 04, edisi Oktober 2017.

Chen, C dan Tsai, D. 2007. How Destination Image and Evaluative Factors Affect Behavioral Intentions. Tourism Management. 28 (4)

Covarrubias, M., 1947. Island of Bali. Alfred. A. Knopf. New York

Dewa Alit Dwija Putra. Patra Aditia. 2016. Ducth Colonialism Symbols at The Relief on Jagaraga Temple, Northern Bali. Bandung Creative Movement 2016. Multidisiplinary Design: Harmonizing Design in Today's Society, Technology and Business. Di akses pada file://D:/user/Downloads/16.24.057_article_f.pdf, Tanggal 16 Maret 2020.

Echtner, Charlotte M. dan Ritche, J.R. Brent. 1991. The Meaning and Measurement of Destination Image. The Journal of Tourism Studies. Volume 2. No. 2.

Frank, M. Roehrig. P. dan Pring, B. 2014. Code Halos: How The Digitals Lives of People, Things, and Organizations Are Changing The Rules of Business. Wiley

Gelder, Sicco van. 2005. Global Brand Strategy: Unlocking Branding Potential Across Countries, Cultures \& Markets. London: Kogan Page Limited.

Govers, R. Go, Frank.M dan Kumar, K. 2007. Promoting Tourism Destination Image. Journal of Travel Research. Volume 46. Issue 1.

Govers, Robert dan Go, Frank, M. 2010. The E-branding of Places. International Place Branding Yearbook 2010. Palgrave Macmillan, a division of Macmillan Publishers Limited.

Hauser, Brigitta dan Schaublin. 2004. "Bali Aga" and Islam: Ethnicity, Ritual Practice, and "Old-Balinese" as an Anthropological Construct. Cornell University Press. Southeast Asia Program Publication at Cornell University. https://www.jstor.org/stable/3351418. 
Justiasta, I Gede. 2015. Tradisi "Ngusaba Bukakak" di Desa Giri Emas, Sawan, Buleleng, Bali dan Potensinya Sebagai Sumber Pembelajaran IPS di SMP. Dalam https://ejournal.undiksha.ac.id/index.php/JJPS/article/view/4848/3662, di akses pada tanggal 16 Maret 2020.

Made Windu Antara Kesiman, Jean-Christophe Burie, Jean-Marc Ogier, Gusti Ngurah Made Agus Wibawantara, I Made Gede Sunarya. 2016. AMADI_LontarSet: The First Handwritten BalinesePalm Leaf Manuscripts Dataset. 15th International Conference on Frontiers in Handwriting Recognition 2016, Oct 2016, Shenzhen, China. pp.168-172.

Kotler, P dan Kellner, L.K. 2012. Marketing Management. Edition 14 ${ }^{\text {th }}$. Pearson Education

Kotler, P dan Amstrong, G. 2014. Prinsip -prinsip Manajemen. Edisi 14. Jilid 1. Jakarta: Erlanggga

Mahika, Elena Cristina. 2011. Current Trends in Tourist Motivation. Cactus Tourism Journal. Volume 2. Issue 2.

Marsaja, I Gede. 2015. Desa Kolok and its Deaf People. Dalam https://www.cdu.edu.au/sites/default/files/the-northerninstitute/cdu_ni_learning_communities_journal_2015_16_print.pdf\#page=60, di akses pada tanggal 16 Maret 2020.

Milman, Ady dan Pizam, Abraham. 1995. The Role of Awareness and Familiarity with a Destination: The Central Florida Case. Journal of Travel Research. Akses pada http://citeseerx.ist.psu.edu/viewdoc/download?doi=10.1.1.949.5488\&rep=rep1 \&type $=$ pdf

Murtana, I Nyoman. Ni Diah Purnamwati. E. Soemaryatmi. Tatik Harpawati. 2018. Tradisi Wisata Desa Sembiran Kabupaten Buleleng. Surakarta: ISI Press

Morgan, Nigel. Annete Pritchard dan Roger Pride. 2004. Destination Branding: creating the Unique Destination Proporsition. Elservier Ltd.

Prasetya, Darmawan. 2018. Local Wisdom and Construction of Inclusion Community: Learning from Disability People Named Kolok in Bali. International Conference on Social and Political Issues (the $1^{\text {st }}$ ICSPI). Volume 2018

Putra, I Dewa Alit Dwija dan Abdulah, Sarena. 2018. Diversity of Cultural Elements at The Reliefs of Pura Desa Lan Puseh in Sudaji Village Northern Bali. $5^{\text {th }}$ Bnadung Creative Movement International Cenference on Creative Industries. Advance in Social Science, Education and Humanities Research. Volume 197

Pramana, Putu Gede Ary. Gede Eka Harsana Koriawan. Luh Suarti. 2015. Hiasan Candi Kurung Pura Beji Desa Sangsit. Jurnal Pendidikan Seni Rupa. Vol.5. No.1 
Prawira, I Gede Yogi Adi. 2013. Pura Beji Sebagai Cagar Budaya Dalam Perspektif Pendidikan di Desa Sangsit, Sawan, Buleleng, Bali. Widya Winayata. Jurnal Pendidikan Sejarah

Ross, G. F. 1993. Ideal and Actual Images of Backpacker Visitors to Northern Australia. Journal of Travel Research. 32 (2)

Siwalatri, Ni Ketut Ayu. Josef Prijomoto. Purwanita Setijanti. 2012. Meaning of Ornament in Balinese Traditional Architecture. Journal of Basic and Applied Scientific Research. 2(7).

Suacana, Wayan Gede. 2011. BUdaya Demokrasi Dalam Kehidupan Masyarakat Desa di Bali. Jurnal Kajian Bali. Volume 01. Nomor 01. April 2011.

Schultz, Don. E and Barnes, Beth E. (1999). Strategic Brand Communication Campaigns. Lincolnwood, IL : NTC Business Books.

Sudewa, Ida Bagus Adi. 2003. Contemporary Use of The Balinese Script. Di akses pada https://www.unicode.org/L2/L2003/03118-balinese.pdf, tanggal 16 Maret 2020.

Tasci, Aslid. A dan Gartner, William C. 2007. Destination Image and Its Functional Relationship. Journal of Travel Research. Volume 45(4)

Trinawindu, Ida Bagus Kt. Cok Alit Artawan. I Wayan AGus Eka Cahyadi. 2015. Pelestarian Prasi Dengan Teknologi Digital. Jurnal Segara Widya. Volume 3. Nomor 1.

Widiastini, Ni Made Ary. Nyoman Dini Andiani. Trianasari. 2012. Strategi Pemasaran Pariwisata di Kabupaten Buleleng, Bali. Jurnal Ilmu Sosial dan Humaniora. Volume 1. Nomor 1.

Widiastini, Ni Made Ary. Putu Indah Rahmawati. Nyoman Dini Andiani. I Putu Gede Parma. 2018. Pengembangan Pariwisata Pedesaan di Kabupaten Buleleng. Seminar Nasional Riset Inovatif. ISBN 978-602-6428-73-8

Wira, Adi. 2018. "Sudaji Bukakak Festival". Diakses pada http://sudajitourism.com/wisata-budaya/

Yusuf, Naufal dan Adnyana, Made. 2019. “Desa Tua di Buleleng Miliki Tradisi Melepasliarkan Buring Pemakan Ulat. Diakses pada https://today.line.me/id/pc/article/Desa+tua+di+Buleleng+miliki+tradisi+mele pasliarkan+burung+pemakan+ulat-2EKQmj 


\section{Profil Penulis}

Ni Made Ary Widiastini pada Fakultas Ekonomi Universitas Pendidikan Ganesha. Dia menyelesaikan D-4 di Prodi Manajemen Kepariwisataan STP Nusa Dua Bali, S-2 pada Prodi Kajian Pariwisata dan S-3 pada Prodi Kajian Budaya di Universitas Udayana.

Putu Indah Rahmawati adalah Dosen Senior di Fakultas Ekonomi Universitas Pendidikan Ganesha. Dia Menyelesaikan D-4 di Sekolah Tinggi Pariwisata Bali, S-2 di Victoria University, Melbourne-Australia dengan mendapat gelar Master of Business in Hospitality and Tourism Management. Kemudian pada tahun 2017 mendapat gelar Ph.D dari Victoria University, Melbourne-Australia dalam bidang Pariwisata.

Fajar Yualida Isti Koma adalah praktisi pariwisata yang sejak tahun 2018 aktif menjadi partner kerja di Program Studi D3 Perhotelan Universitas Pendidikan Ganesha (Undiksha). Dia menyelesaikan studi di D3 Perhotelan Undiksha pada tahun 2011 Kemudian pada tahun 2013 mendapat gelar S.ST.Par dari Sekolah Tinggi Pariwisata Bali International dalam bidang pariwisata. 